\title{
Cretaceous Orbitolinidae (Foraminifera) from Onshore and Offshore South-West England
}

\author{
M.D. SIMMONS \\ BP Exploration, \\ Stockley Park, \\ Uxbridge, \\ Mddx. UB11 1BP, U.K.
}

\author{
C.L. WILLIAMS \\ Tethyan Consultants, \\ Branshaw House, Downgate, \\ Callington, \\ Cornwall PL17 8J, UK.
}

\begin{abstract}
The occurrence of orbitolinids in onshore and offshore South-West England is fully documented for the first time. Palorbitolina lenticularis is known from the Early Aptian - Late Barremian sediments of the offshore Fastnet Basin, and may also occur in the Aptian Farringdon Greensand. Late Albian Orbitolina sefini occurs in the Wolborough Limestone of Devon, whilst at Haldon, Devon, the orbitoline faunas are of Early Cenomanian age and referable to Orbitolina cf. concava. The orbitolinids from the Upper Greensand of the south-east Devon coast and the Fastnet Basin cannot be precisely identified, but belong to the Late Albian - Early Cenomanian O. sefini - O. concava plexus. Previous records of Orbitolina from the Upper Greensand at Wilmington are shown to be mistaken. These records are in fact referable to the sponge Porosphaera. The precise identification of some of the orbitolinids from South-West England supports the ages of the Wolborough Limestone and Haldon Sands suggested by Hamblin \& Wood (1976). It is thought that orbitolinids migrated from Iberia to South-West England via the South-West Approaches during the Late Albian. J.micropalaeontol., 11(1): 21-30, June 1992.
\end{abstract}

\section{INTRODUCTION}

The Orbitolinidae are a family of complex agglutinating larger Foraminifera, typical of the Tethyan Realm. Although known from Jurassic and Palaeogene sediments, they are most typical of, and were most diverse, during Early and mid-Cretaceous times. The occurrence of orbitolinids in the Early and mid-Cretaceous sediments of onshoreand offshoreSouth-West England represents some of the most northerly records of this foraminiferal group.

Orbitolinids are known from Early Cretaceous sediments of the Fastnet Basin in the offshore area (and more rarely the Lower Greensand of the onshore area) and from the mid-Cretaceous Upper Greensand and equivalents in both the onshore and offshore areas. In all cases the occurrence of orbitolinids provides valuable chronostratigraphic information, since orbitolinid species have relatively restricted stratigraphic ranges. This is important, since the formations in which the orbitolinids occur are usually poorly dated by macrofossils and other microfossil group.

In this paper, previous and new records of Orbitolinidae from South-West England are redescribed in terms of the current taxonomic nomenclature. The local and regional stratigraphic significance of the faunas is discussed, as are the palaeobiogeographic implications.

\section{PREVIOUS WORK}

The position of the locations mentioned in the text below are shown in Fig 1.

The first records of orbitolinids from anywhere in the United Kingdom can be traced back to Godwin-Austin (1842) who stated "The Orbitolites [in this sense, a junior synonym of Orbitolina] which occur sparingly on Haldon, are exceedingly numerous in beds below Lindridge Hill...". Both these localities are in south-east Devon. Parker and Jones (1860) were aware of the occurrence of Orbitolina in the mid-Cretaceous sediments of Devon. They referred these occurrences to the species Orbitolina concava Lamarck. However, some of their records of Orbitolina (e.g. from the chalk and chalk marl) are in fact misidentifications of the sponge Porosphaera as first pointed out by Hinde (1904). Sporadic records then occur in studies made during the latter part of the nineteenth century and the first half of this century on the Upper Greensand of South-West England (e.g. Meyer, 1874; Jukes-Browne and Hill, 1900). More recently Hamblin \& Wood (1976), Edwards (1979) and Selwood et al. (1984) have documented the occurrence of orbitolinids in the UpperGreensand equivalents of the Haldon Hills and Wolborough areas of Devon.

It was not until the work of Hart, published in a series of papers (Hart, 1971, 1973, 1982; Hart \& Tarling, 1974; Carter Hart, 1977; Hart et al., 1979a; Hart \& Williams, 1990) that the orbitolinids of South-West England were considered in any detail, and their applications for stratigraphic correlation realised. Hart and his colleagues recorded Orbitolina from Wolborough, the Haldon Hills, the south-east Devon coast and Warminster. Their occurrence was used to suggest that the upper part of the UpperGreensand was Early Cenomanian in age. On the basis of a preliminary analysis of external dimensions of the orbitolinids from the Upper Greensand and its equivalents, Hart et al. (1979a) suggested that the Wolborough faunas were older than those of the Haldon Hills. The Wolborough faunas compared well with those from Late Albian sediments in Portugal, whilst the Haldon Hill faunas compared well with those from the Early Cenomanian of Ballon, France.

Schroeder et al. (1986) revised the taxonomy of the Wolborough orbitolinids. They were placed in the species Orbitolina sefini Henson on the basis of internal structures, notably size and shape of embryonic apparatus and chamberlets. 


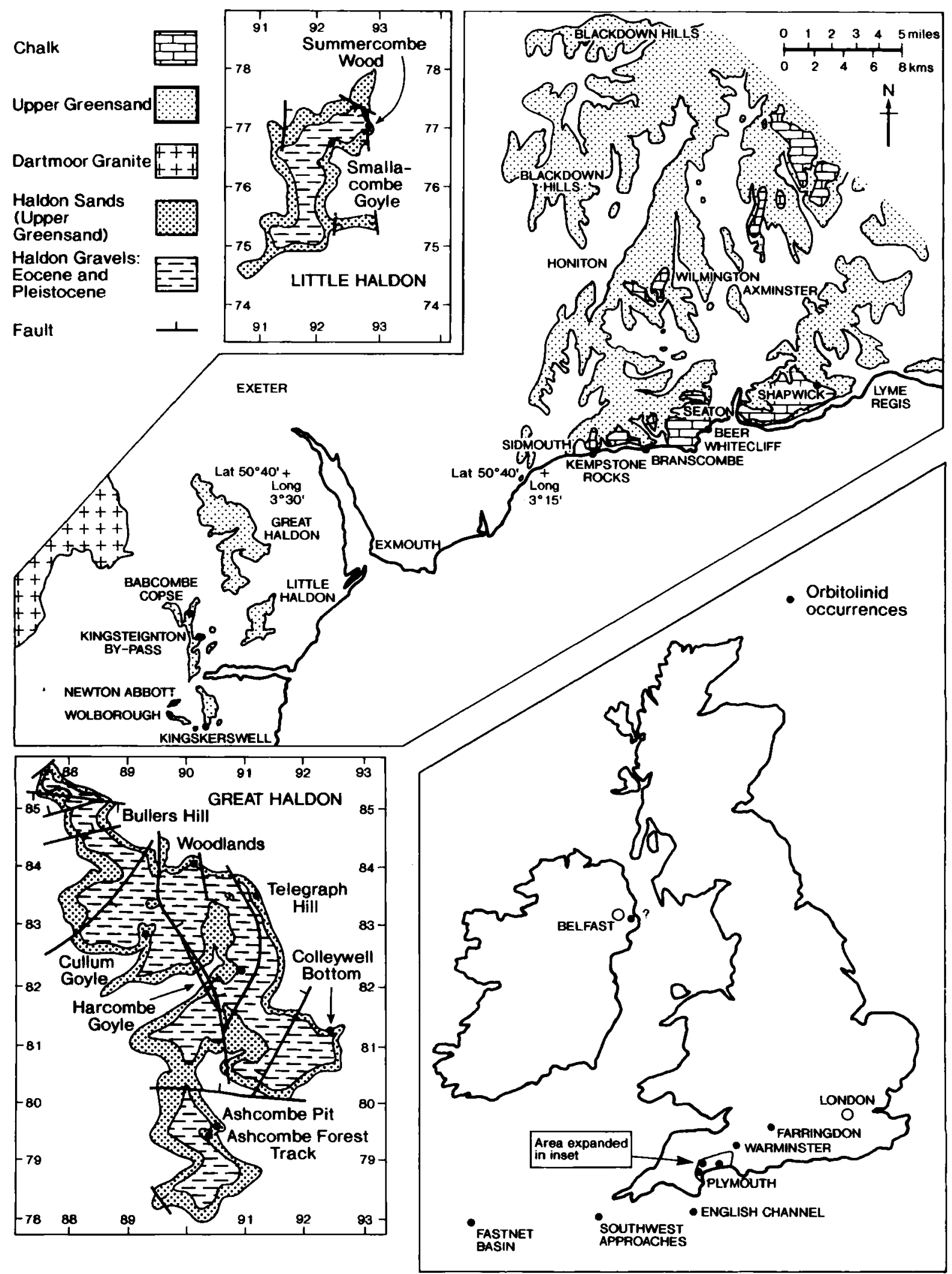

Fig. 1. Location map showing orbitolinid occurrences in the onshore and offshore British Isles area, and locations mentioned in the text (in part after Hamblin \& Wood, 1976). 
Williams et al. (1988) discussed the occurrence of other benthonic foraminifera from the Upper Greensand of South-West England. This work indicated that the lower part of the UpperGreensand (that below the Orbitolina occurrences) was Late Albian.

Hume (1897) recorded Orbitolina from the Hibernian Greensand of Northern Ireland, and this interesting northerly record has been repeated by Hancock (1961) and Reid (1971). However, Carter \& Hart (1977) and Reid (pers. comm., 1984) note that actual specimens to confirm this record are lacking. McGugan (1953) in his review of Upper Cretaceous foraminifera from Northern Ireland does not mention Orbitolina.

Ainsworth et al. $(1985,1987)$ and Ainsworth \& Horton (1986) documented the occurrence of orbitolinids from Wealden/Lower Greensand and Upper Greensand equivalents of the Fastnet Basin. Curry et al. (1970) and Andreieff $e t$ al. (1975) have recorded orbitolinids from mid-Cretaceous sediments of the Western Approaches to the English Channel.

\section{ORBITOLINID TAXONOMY}

As discussed by Schroeder (e.g. 1962, 1963, 1975) and Hofker $(1963,1966)$, the internal structure of orbitolinids is the most critical feature for taxonomic separation. Within the subfamily Orbitolininae (Orbitolina sensu lato), the most important feature is the macrospheric embryonic apparatus (see Fig. 2). The structure and size of this delimits genera and species, and allows for the construction of phylogenetic lineages. Hofker $(1963,1966)$ considered that there was only one phylogenetic lineage within the Orbitolininae, and that this could be grouped underonespecies name - Orbitolinalenticularis (Blumenbach). However Schroeder (e.g. 1975) has shown this to be incorrect. A number of phylogenetic lineages exist within the Orbitolininae which allow for separation into distinct genera and short ranging and transitional species. This taxonomy is now widely accepted as being correct.

For further details of the morphological terminology used in describing the orbitolinids see Schroeder (1975) and Arnaud-Vanneau (1980).

\section{PALORBITOLINA OCCURRENCES}

Orbitolinids have been reported from the Early Aptian-Late Barremian (Wealden - Lower Greensand equivalents) of the Fastnet Basin by Ainsworth et al. (1985). These occurred in the Cities Service exploration well 63/10-1. Examination of specimens kindly supplied by Dr Ainsworth, revealed them to belong to the species Palorbitolina lenticularis (Blumenbach) (Pl. 1, figs 1,2).

The monotypic genus Palorbitolina is distinguished by a relatively simpleembryonic apparatus (Schroeder, 1963,1975). This consists of an apically situated spherical embryonic chamber (a combined proloculus and deuteroconch), and in advanced specimens, peri-embryonic chamberlets (Pl.1,fig. 2). The deuteroconch and peri-embryonic chamberlets typically show a surface division by septa. The lack of a subembryonic zone distinguishes this species from the more complex Albian - Cenomanian genus Orbitolina which is also found in the Fastnet Basin.

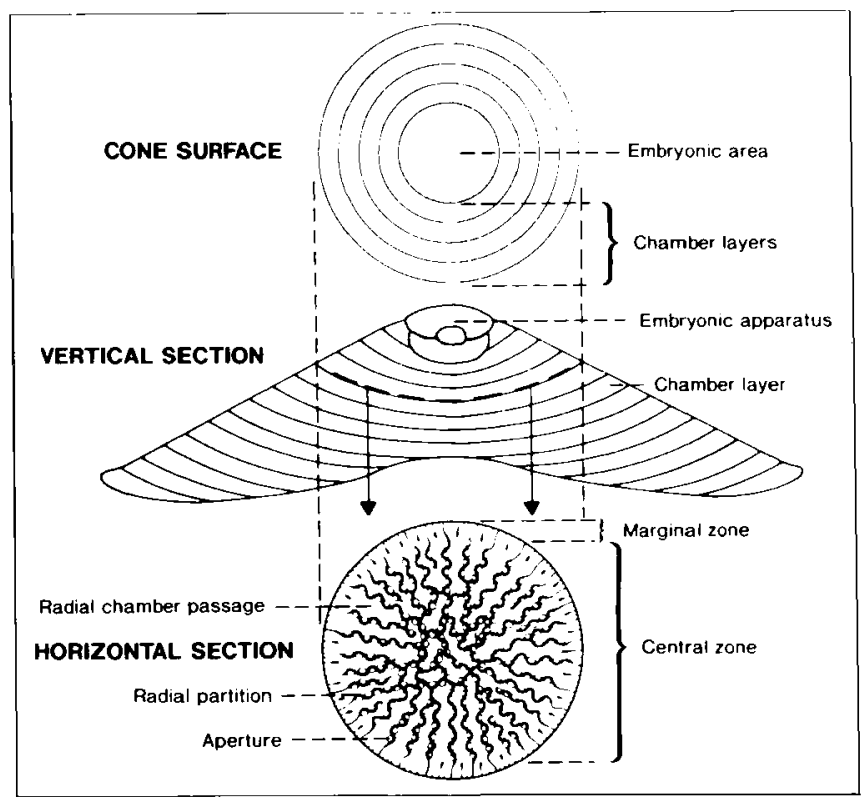

Fig. 2. Orbitolinid internal structure (after Schroeder, 1975).

Gusic (1981) and Simmons \& Hart (1987) suggested that progressive increases in the size and complexity of the embryonic apparatus could be used to distinguish different stages with the evolution of $P$. lenticularis. These in turn, could enable a subdivision of the Late Barremian - Early Aptian time-span. However, large populations are needed to undertake this with confidence and the limited material available to us in this study is thus unsuitable.

Orbitolinids are known to occur in the Farringdon Greensand (Lower Greensand equivalent) (Natural History Museum, London, Curry Collection). Some of these specimens have been examined in thir-section, but unfortunately a diagnostic embryonic apparatus was not found. However, the Aptian age of the sediments suggests that these orbitolinids are likely to be $P$.lenticularis. The specimens are associated with Choffatella decipiens Schlumberger (Hart, pers. comm., 1990) a foraminifera with which $P$. lenticularis often occurs.

$P$. lenticularis has a known stratigraphic range of Late Barremian - Early Aptian (Schroeder, 1975; Simmons, 1990). This compares favourably with the associated microfauna and microflora recorded by Ainsworth et al. $(1985,1987)$.

The validity of the genus Palorbitolina has been established by Schroeder \& Simmons, 1988, 1989; ICZN, 1990).

\section{ORBITOLINA OCCURRENCES}

As noted above, there are relatively numerous records of orbitolinids from the mid-Cretaceous Upper Greensand and equivalents of onshore and offshore South-West England. There are also more questionable records from Northern Ireland.

We have examined material from Wolborough, the Haldon Hills, Wilmington, and the south-east Devon coast. We have also studied material from the mid-Cretaceous sediments of the Fastnet Basin.

The most abundant faunas of orbitolinids from onshore 


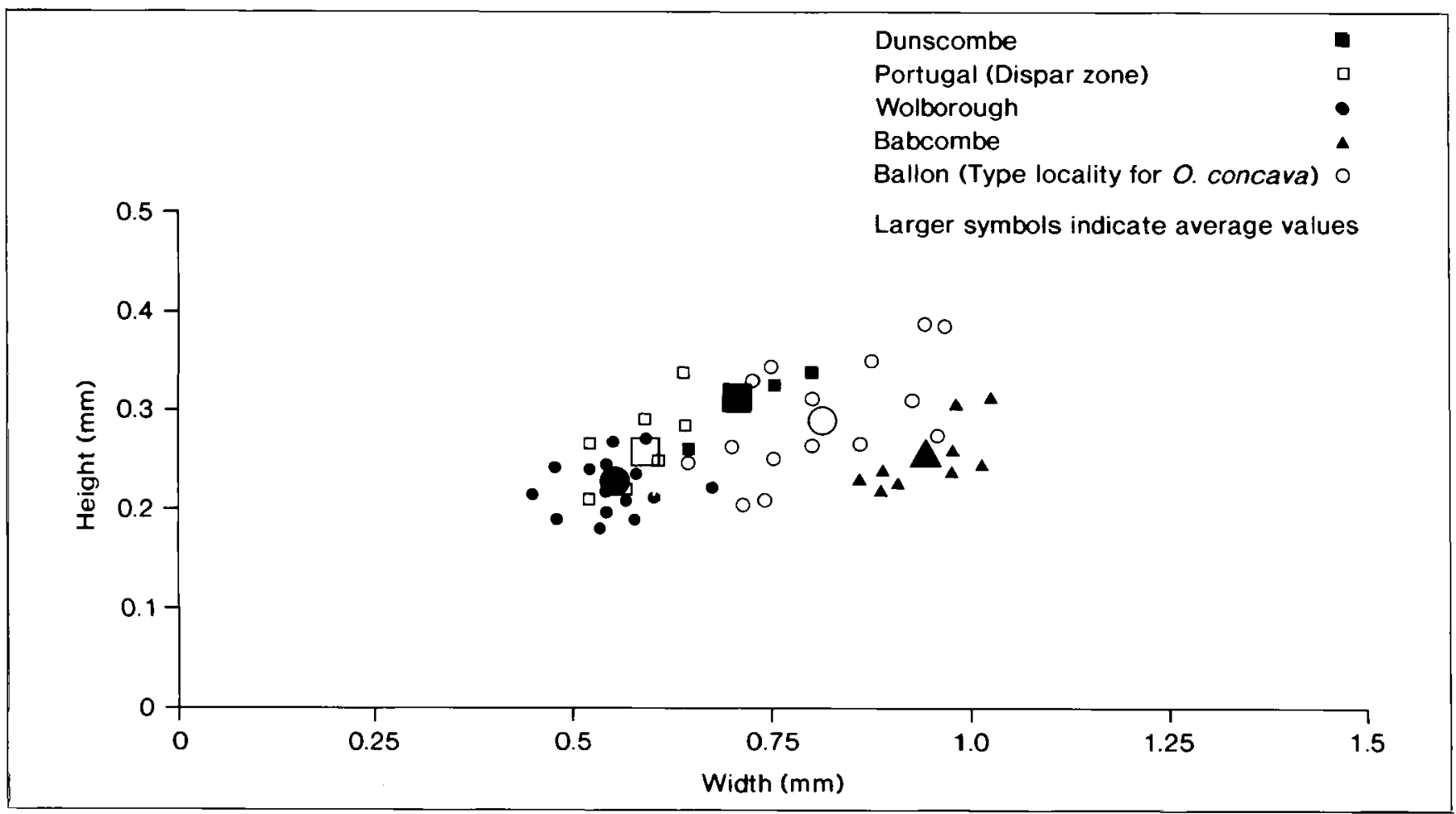

Fig. 3 Graphical plot of embryonic apparatus measurements for Orbitolina from Dunscombe, Wolborough, Babcombe Copse (Haldon Hills), Portugal and Ballon, France.

South-West England occur in Upper Greensand equivalent sediments at Wolborough, near Newton Abbot, South Devon (Fig. 1). Schroeder et al (1986) demonstrated that these occurrences could be referred to the species Orbitolina sefini. O. sefini has a complex embryonic apparatus, which in our specimens has a typical diameter of between 0.5 and $0.72 \mathrm{~mm}$ (see Fig. 3), with an ellipsoidal protoconch (diameter $0.18-$ $0.24 \mathrm{~mm}$ ) surrounded by a subdivided deuteroconch and a considerably thinner, but relatively large, subembryonic zone (Pl.1, fig. 3). The species is distinguished by exclusively triangular cross-sections of the radial partitions and the chamber passages within the radial zone of the chamber layers (Schroeder, 1985a, Pl. 30, fig. 1; Schroeder et al., 1986, Fig. 2d, f and Pl. 1, fig. 4). In Orbitolina concava the chamber passages show sub-rectangular cross-sections and are separated by small, radial partitions (e.g. Schroeder 1985b, Pl. 29, Figs 7-8). O. sefinican also be distinguished from $O$. concava by its smaller embryonic apparatus diameter (in $\mathrm{O}$. concava typically $0.7-0.9 \mathrm{~mm}$ ) (Schroeder, 1985b, see also Fig. 3).

According to Schroeder (1985a) O. sefini has a range from intra-Late Albian to intra-Early Cenomanian. The Wolborough limestones in which $O$. sefini occurs have been correlated with the Woodlands Sand Member of Haldon Hill (Hamblin \& Wood, 1976). The Woodland Sands Member was thought by Hamblin \& Wood (1976) to be Late Albian on the basis of a debatable correlation to the Chert Beds of south-east Devon, and the presence of two poorly preserved ammonites thought to have their provenance in the Woodland Sands Member. However, the molluscan fauna found within the Woodlands Sand Member was said to have a Cenomanian aspect. As shown in Fig. 3, the embryonic apparatus diameters for $O$. sefini from Wolborough are close to those recorded for Late Albian (Dispar Zone) O. sefini from Portugal. This tends to confirm a Late Albian age for the Wolborough occurrences.

We have also noted the occurrence of $O$. sefini in samples from the Wolborough Limestone equivalent or Woodlands Sand Member equivalent in the road cutting of the Newton Abbot py-pass just north of Newton Abbot (PI. 1, figs 4, 5).

Orbitolinids are also common at a stratigraphically higher level than at Wolborough in the Upper Greensand and Cenomanian Limestone equivalents of the Haldon Hills (see Fig. 1). These occurrences are in the Cullum Sands with Chert

Explanation of Plate 1

Figs 1, 2. Palorbitolina lenticularis (x100), Barremian - Aptian, Fastnet Basin, Cities Services well 63/10-1. Detail of embryonic apparatus. Fig. 2 shows a form with peri-embryonic chamberlets.

Fig. 3 Orbitolina sefini (x40), Late Albian, Wolborough Limestone, Wolborough, Devon.

Fig. 4. O sefini ( $x 40)$, Late Albian, Wolborough Limestone, Newton Abbot By-pass, Devon. Note triangular shape of radial partitions and chamber passages.

Fig.5. O. sefini (x100), Late Albian, Wolborough Limestone, Newton Abbot By-pass, Devon. Detail of embryonic apparatus.

Fig.6. Orbitolina cf. concava (x100), Early Cenomanian, Cullum Sands with Cherts Member, Babcombe Copse, Haldon, Devon. Detail of embryonic apparatus. 


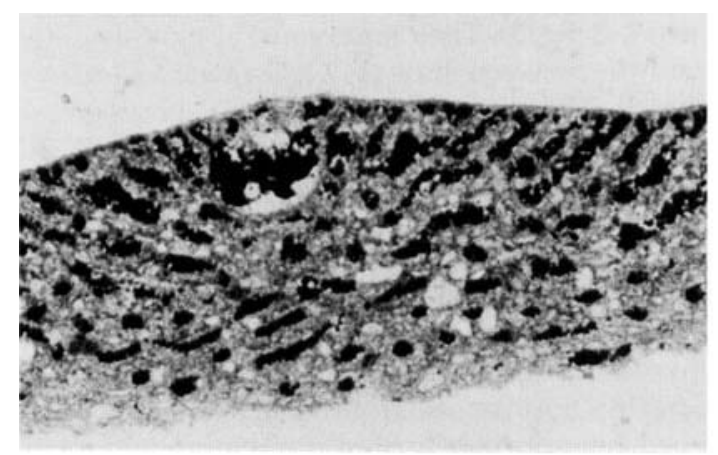

1

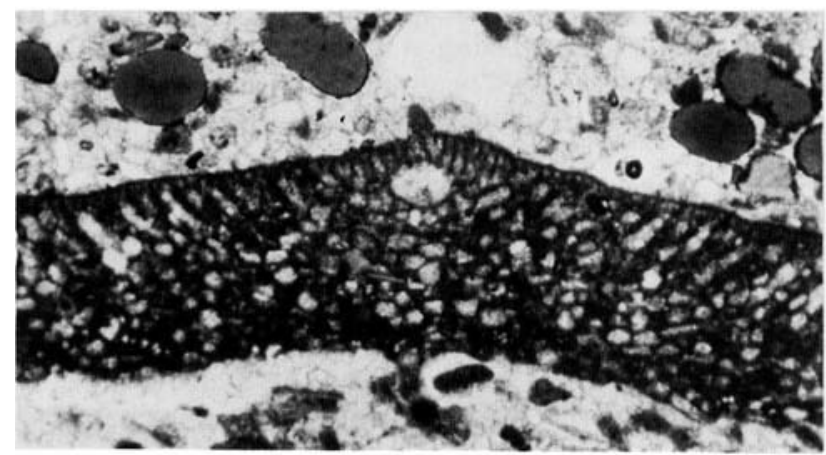

3

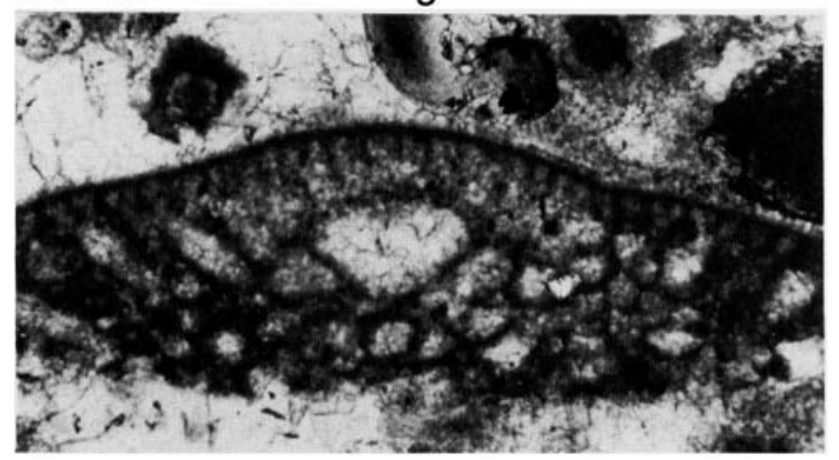

5

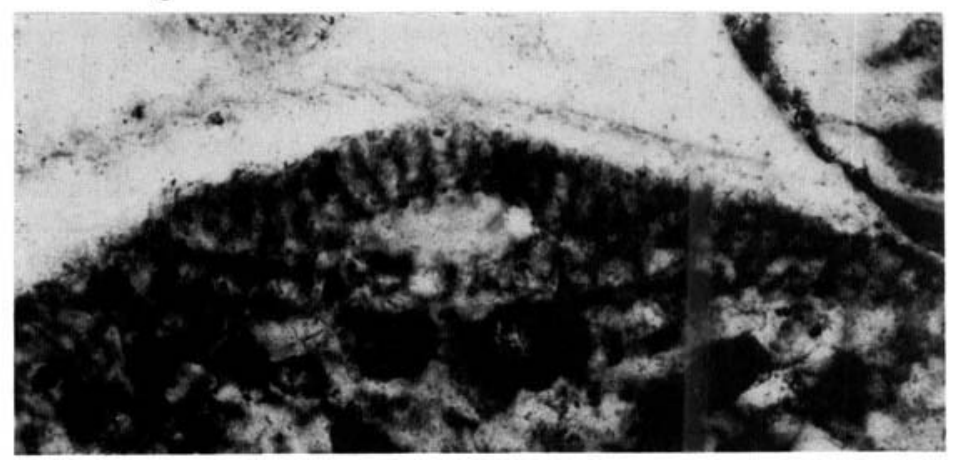

6

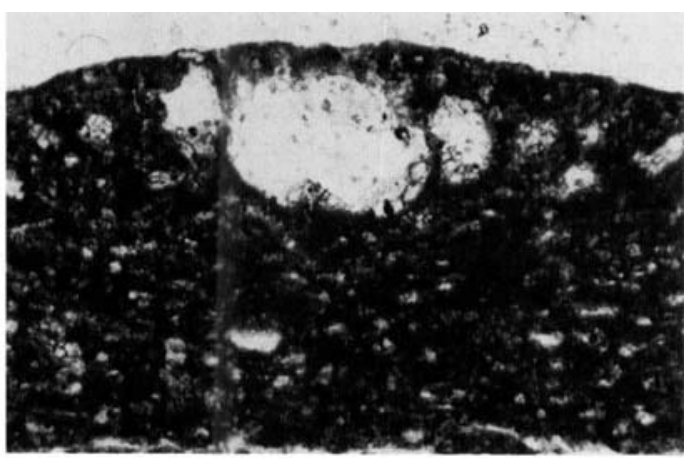

\section{2}

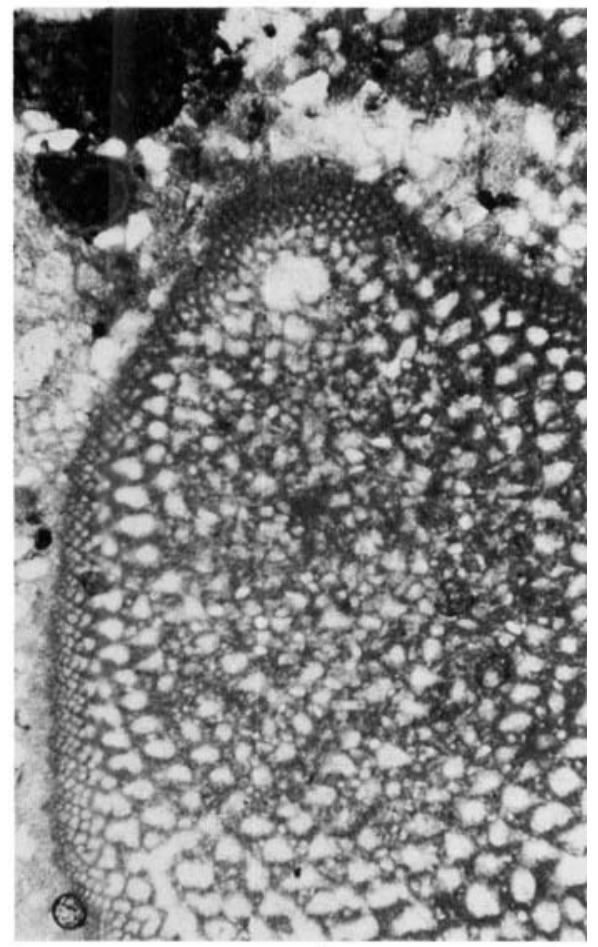

4 
Member of the Haldon Sands Formation (Hamblin \& Wood, 1976). Hamblin \& Wood (1976) suggest that this unit correlates with either the non-sequence between the Upper Greensand and Cenomanian, and/or the lower part of the Cenomanian Limestone (Bed A1) (= Beer Head Limestone Formation, Pounds Pool and Hooken Members of Jarvis \& Woodroof, 1984). This correlation indicates an Early Cenomanian age for the Cullum Sands with Chert Member, an age substantiated by the occurrence of Early Cenomanian ammonites in the Haldon section which are thought to have been derived from the Cullum Sands.

The orbitolinids are poorly preserved and are often silicified (Pl. 1, fig. 6 and Pl. 2, fig. 1). However, they can be seen to posses a complex embryonic apparatus divisible into a lenticular protoconch surrounded by a subdivided deuteroconch and a thin subembryonic zone. This indicates these occurrences can be referred to the genus Orbitolina. Of note is the diameter of the embryonic apparatus. It is greater than that of the $O$. sefini specimens from Wolborough having an average value of $0.95 \mathrm{~mm}$ (see Fig. 3). This suggests that these specimens are not referable to $O$. sefini and have a closer affinity to $O$. concava. Indeed, the diameter of the embryonic apparatus of the Haldon Hills specimens is slightly greater than that of topotypic specimens of $O$. concava from Ballon, France (see Fig. 3 and Pl. 2, Fig. 2). Unfortunately the poor preservation of the specimens from the Haldon Hills does not allow for recognition of the characteristic sub-rectangular cross-sections of chamber passages $O$. concava. Thus these specimens are referred to Orbitolina sp. cf. O. concava.

Orbitolina concava has a well defined stratigraphic range in which it is restricted to the Early Cenomanian. The likely recognition of this species confirms the results of Hart et al. (1979a) who suggested the Cullum Sands orbitolinids had a close affinity with $O$. concava from the Early Cenomanian of Ballon, whilst the Wolborough orbitolinids had a closer affinity with Late Albian Orbitolina from Portugal. This work was based as a comparison on external dimensions of the orbitolinids, a criteria that is not usually considered valid for speciation of orbitolines.

A limited number of orbitolines have been examined from the Upper Greensand of the south-east Devon coast. These are specimens collected by Dr Graham Elliott from a level in the uppermost Chert Beds or lowermost Top Sandstones at Dunscombe and referred to by Hofker (1963) and Carter \& Hart (1977). They are housed in the Natural History Museum, London (registration numbers P45079 and P43429). Despite extensive searches by the current authors, the level with Orbitolina could not be located on the south-east Devon coast. A few of the Dunscombe specimens were thin-sectioned.
Although poorly preserved, the embryonic apparatus of these specimens clearly places them in the $O$. sefini - $O$. concava plexus (Pl. 2, fig. 3). Their embryonic apparatus dimensions plot midway between those of $O$. sefini and those of $O$. concava (see Fig. 3). The marginal zone of these specimens shows a close similarity to O. sefini from Wolborough (Pl. 2, fig. 4). However, it must be stressed that the precise identity of these orbitolinids remains uncertain.

Similarly, it has not proved possible to provide a precise identification of the orbitolinids found in the glauconitic sands of the Fastnet Basin (Upper Greensand equivalent) and first mentioned by Ainsworth et al. (1985). Loose specimens provided by Dr Ainsworth from the BP well 56/10-1 were thin sectioned, but only poorly preserved embryonic apparatuses were observed. However, these and the nature of the chamber layers suggest that these specimens belong in the O. sefini- $O$. concava plexus. Using a variety of microfossil groups, Ainsworthet al.(1987) suggested that the sediments containing these orbitolinids were of Early Cenomanian age.

It has not been possible to examine orbitolinid specimens from the Warminster Greensand (Carter \& Hart, 1977), or the Hibernian Greensand of Northern Ireland. However, the Early Cenomanian age of the sediments these orbitolinids are recorded from suggests they are likely to be within the $O$. sefini -O. concava plexus.

\section{"ORBITOLINA" FROM THE UPPER GREENSAND AT WILMINGTON}

Of interest is the record of Orbitolina from the Upper Greensand exposed beneath the Wilmington Sands (Beer Head Limestone Formation equivalent) at Wilmington, east Devon (see Figs 1 and 4) (e.g. Carter \& Hart, 1977; Hart, 1982, 1983). We have been able to examine specimens from White Hart Pit, Wilmington collected by Prof. Hart, Prof. Murray and Dr Curry (the latter held in the Natural History Museum, London). Whilst these specimens resemble orbitolinid foraminifera externally, thin-sections of the specimens reveal them to have a completely different structure which is non-foraminiferal (Pl. 2, fig. 5). Comparison with material from other fossil groups in the Natural History Museum, London, shows that these specimens can be referred to the sponge genus Porosphaera. Jukes-Brown and Hill (1900) recorded Porosphaera urceolata from the uppermost Upper Greensand at Warminster. It is likely that the fossil found by Jukes-Brown and Hill is the same as that found at Wilmington. However, assignment to the species P. urceolata (a junior synonym of $P$. pileolus according to Hinde (1904)) is doubtful because this species is typical of the chalk and is somewhat larger and more spherical than the Wilmington specimens.

\section{Explanation of Plate 2}

Fig. 1. Orbitolina cf. concaza ( $x 40$ ), Early Cenomanian, Cullum Sands with Cherts Member, Babcombe Copse, Haldon, Devon.

Fig. 2. Orbitolina concava $(x 40)$, topotype material, Early Cenomanian, Ballon, Sarthe, France.

Fig. 3. O. sefini-O. concava (x 100), close to Albian/Cenomanian boundary, upper Chert Beds/Top Sandstones, Dunscombe Quarry, south-east Devon. Detail of embryonic apparatus. Natural History Museum specimen P.45079.

Fig. 4. O. sefini - O. concava ( $x 40)$, close to Albian/Cenomanian boundary, upper Chert Beds/Top Sandstones, Dunscombe Quarry, south-east Devon. Detail of marginal zone. Compare this to that for O. sefini figured by Schroeder et al. (1986), Fig. 2e. Natural History Museum Specimen P.43429.

Fig.5. Porosphnera sp. (x20), Early Cenomanian? Upper Greensand, White Hart Pit, Wilmington, Devon. 


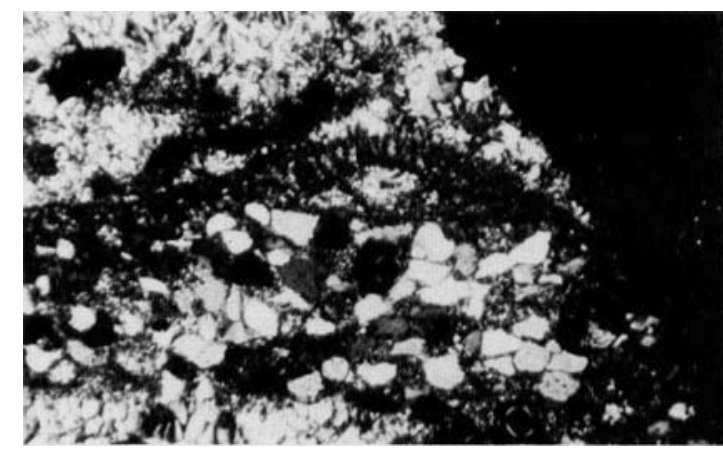

1

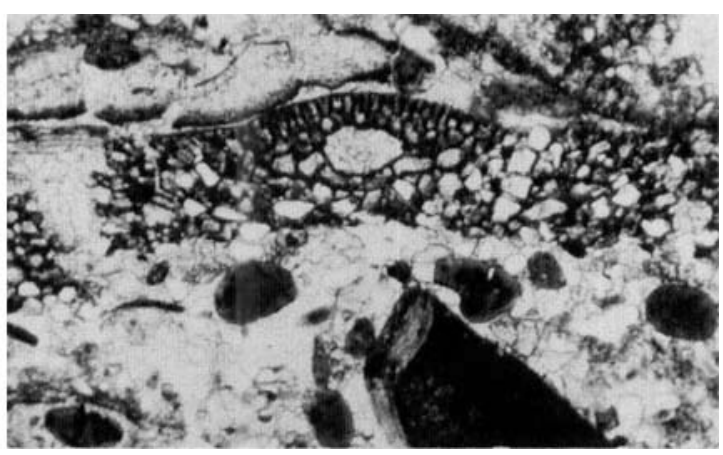

2

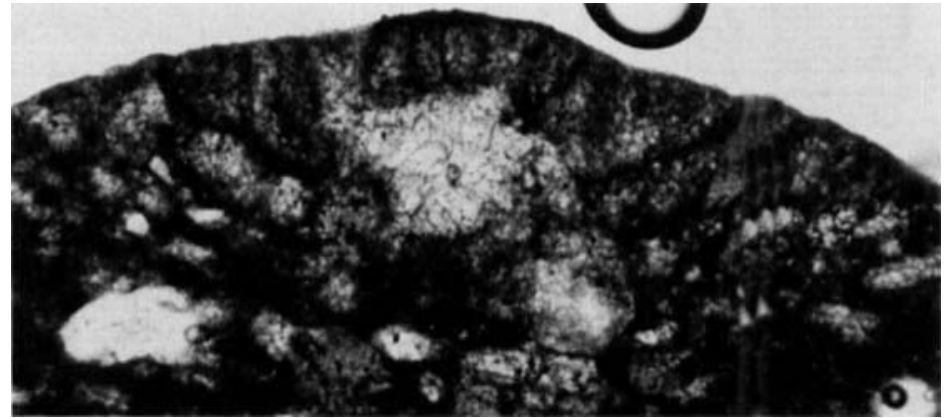

3
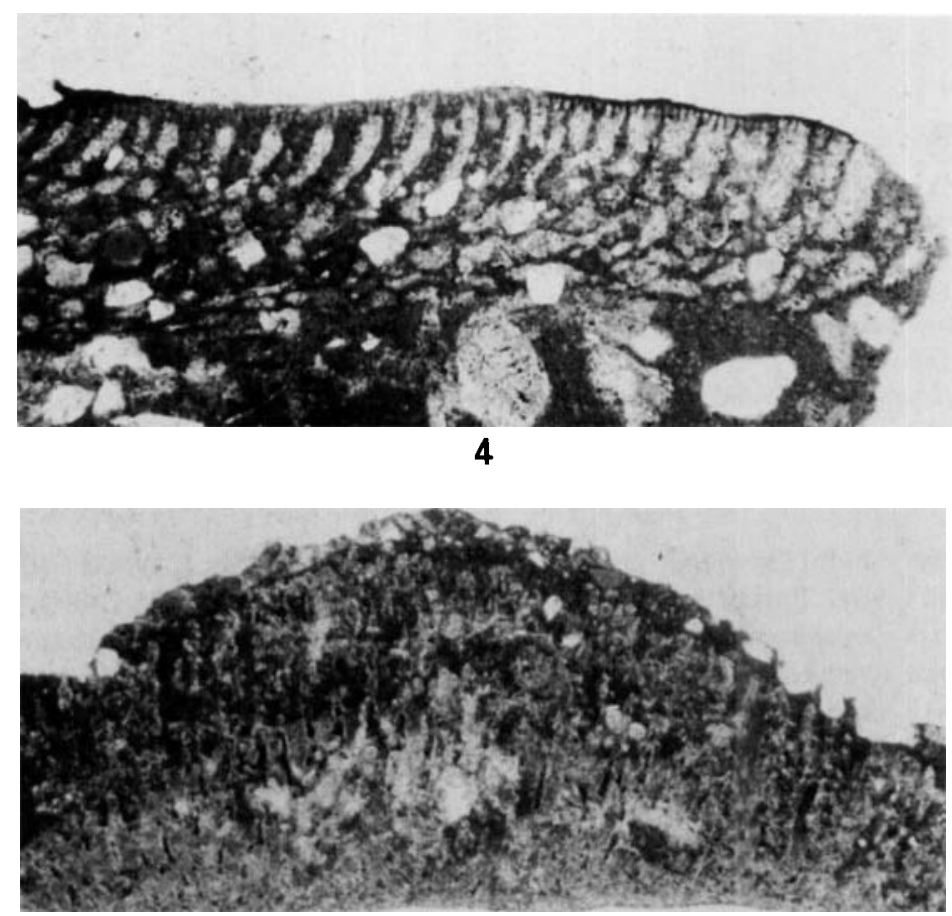


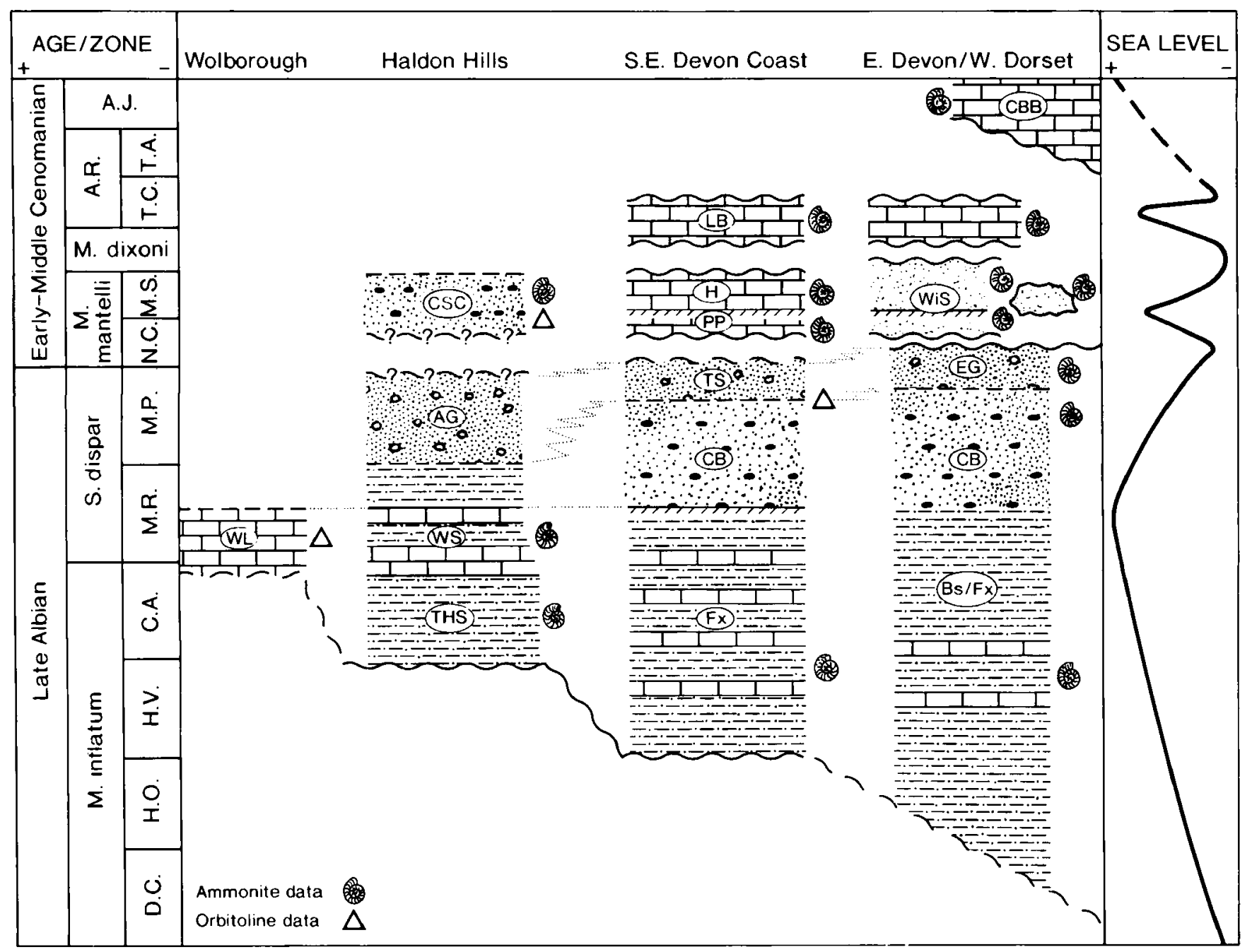

Fig. 4 Chronostratigraphic Summary Chart for the Late Albian - Middle Cenomanian of South-West England. Ammonite zonation follows Owen (1984), Wright $e t$ al. (1984) and Hancock (1989). A.J = A jukesbrowenei, T.A $=$ T. acutus, T.C $=$ T. costatus, A.R. $=A$. rhotomagense, M.S $=$ M. saxbii, $\mathrm{N} . \mathrm{C}=\mathrm{N}$. carcitanensis, $\mathrm{M} . \mathrm{P}=\mathrm{M}$. perinflatum, $\mathrm{R}=\mathrm{M}$. rostratum, $\mathrm{C} . \mathrm{A}=\mathrm{C}$. auritus, $\mathrm{H} . \mathrm{V}=\mathrm{H}$. varicosum, H.O $=$ H. orbignyi, D.C $=$ D. cristatum. Lithostratigraphy abbreviations are as follows:

WL $=$ Wolborough Limestone, THS $=$ Telegraph Hills Sand Member, WS = Woodlands Sands Member, AG = Ashcombe Gravels Member, CSC $=$ Cullum Sands with Cherts Member, Fx = Foxmould Sands, $\mathrm{CB}=$ Chert Beds, $\mathrm{TS}=$ Top Sandstones, $\mathrm{PP}=$ Pounds Pool Member, $\mathrm{H}=\mathrm{Hooken}$ Member, LB = Little Beach Member, BS = Blackdown Sands, EG = Eggerdon Grit, WiS = Wilmington Sands, CBB $=$ Chalk Basement Beds. Sea-level curve shows relative change of coastal onlap. For further discussion of this figure see Simmons et al. (1991).

This is not the first time that Porosphaera and Orbitolina have been confused. According to Hinde (1904), Parker \& Jones' (1860) records of Orbitolina are in fact of Porosphaera. This is not strictly true. Parker \& Jones (1860) mix records of both true Orbitolina (e.g. from the Haldon Hills) with those of Porosphaera (e.g. from the Chalk). It is uncertain if the mention of Orbitolina from the Warminster Sands by Parker \& Jones (1860) refers to true Orbitolina or to Porosphaera.

\section{STRATIGRAPHIC SIGNIFICANCE}

The Upper Greensand of south-east Devon is currently subdivided into three informal units; the Foxmould Sands, the Chert Beds, and the Top Sandstones (see Fig. 4). A paper introducing a formal lithostratigraphy is in preparation. Further west, in the Haldon Hills area, a formal stratigraphy has been proposed by Hamblin \& Wood (1976) (see Fig. 4). It is further described by Selwood et al. (1984).

However, problems exist with the lithological correlation of the Haldon Hills succession with that of the south-east Devon coast. There has also been disagreement over the chronostratigraphic correlation of the sections. Hart (1971) suggested that the majority of the Chert Beds and the Top Sand stones of the coastal sections were of Early Cenomanian age, based on the foraminiferal fauna (including Orbitolina). By correlation with the Haldon Hills (see Carter \& Hart, 1977, Fig.46) much of the Haldon Hills section is therefore also Early Cenomanian. Hamblin \& Wood (1976) whilst agreeing that the upper part of the Haldon Hills section is Cenomanian, considered the majority of the coastal section to be Late Albian. Their argument was based on lithostratigraphic 
correlation and the occurrence of a Dispar Zone (Late Albian) ammonite fauna in the upper Chert Beds of Shapwick Grange Quarry (Fig. 1).

The critical Dispar Zone ammonite fauna from Shapwick Grange Quarry is an important line of evidence for suggesting that the majority of the Upper Greensand is of Late Albian age. Although neither Hart et al. (1979b) nor Jarvis et al. (1987) could confirm a Late Albian age for the ammonite bearing horizon at Shapwick Grange using a variety of microfossil groups, Owen (pers. comm. 1990) confirms that the ammonite fauna is of latest Albian age (uppermost Dispar Zone) and that it is not a remané deposit similar to those known from east Dorset (Carter \& Hart, 1977).

Whilst the Shapwick Grange Quarry ammonite fauna indicates that the Chert Beds must be Late Albian (contrary to the view of Hart 1971, et. seq.) it does not rule out the possibility that the Top Sandstones are Early Cenomanian. This was suggested by Kennedy (1970) who provided ammonite evidence that the Eggerdon Grit was, at least in part, Early Cenomanian. The Top Sandstones is the lateral equivalent of the Eggerdon Grit (see Fig. 4), although note that this coarse sandy facies at the top of the Upper Greensand is likely to be diachronous.

The orbitolinids found in the Upper Greensand of South-West England give some useful indications about correlation of this marginal facies between localities. The Wolborough orbitolinids can be assigned to O. sefini which suggests an intra Late Albian - intra Early Cenomanian age. In fact, the embryonic apparatus measurements plot very close to those for Late Albian O. sefini from Portugal (see Fig. 3). This tends to support the Late Albian age ascribed to these sediments by Hamblin \& Wood (1976) and their tentative correlation with the Late Albian Woodlands Sands Member of the Haldon Sands Formation at Haldon Hill. It is clear that the orbitolinids from the Cullum Sands with Chert Member of Haldon Hill belong to a separate, younger population $(O$. cf. concava), most likely Early Cenomanian. Again, this confirms the age ascribed to this unit by Hamblin \& Wood (1976).

However, the critical question of correlation of the Haldon Hills section with that of the south-east Devon coast still remains essentially unanswered. The simplistic correlation of the orbitolinid-rich Cullum Sands with Chert to the orbitolinid-bearing Top Sandstones/Uppermost Chert Beds at Dunscombe on the south-east Devon coast is thought unlikely, and in any case, the orbitolinids studied from Dunscombe cannot be precisely identified at present. Rather, the definite Early Cenomanian age suggested for the Cullum Sands with Cherts indicates a correlation with the lower part of the Beer Head Limestone to be likely. We suggest that lithologically, the Ashcombe Gravels Member correlates with the Top Sandstones and upper Chert Beds (Fig. 4). These correlations are in broad agreement with some of the suggestions of Hamblin \& Wood (1976).

It is known that embryonic apparatus size in orbitolinids increases with time within a phylogenetic lineage (e.g. Schroeder, 1975; Gusic, 1981), thus within the O. sefini-O concava plexus we can assume that greater embryonic apparatus size indicates a younger age. Therefore Figure 3 suggests that three distinct populations of Orbitolina occur in the Upper
Greensand: the Wolborough Late Albian population, which is older than the Dunscombe population, which in turn is older than the Early cenomanian Babcome Copse population. These relative age assignments support the correlations shown in Fig. 4.

\section{PALAEOBIOGEOGRAPHIC SIGNIFICANCE}

Hartet al. (1979a) discussed the possible colonisation pathway of Orbitolina and came to the conclusion that the orbitoline occurrences in South-West England had probably arrived by way of the Paris Basin. They pointed out that orbitolines recorded from the English Channel Basin and the South-West Approaches Basin (Andreieff et al., 1975; Curry et al., 1970) have been assigned an Early Cenomanian or Albian Cenomanian age and "that it is difficult to see how this accepted 'Tethyan' genus could appear in the U.K. earlier than in these more southern localities". However the age of these orbitolinids from the English Channel Basin and the South-West Approaches is quite generalized, and as shown above, it is likely that both Late Albian and Early Cenomanian orbitolinids occur in South-West England.

The occurrence of Late Albian O. sefini in both Portugal (Rey ef al., 1977) and South-West England suggests that there may have been a migration pathway from the Iberian Peninsula via the South-West Approaches to South-West England. Such a pathway can be supported by the palaeogeography proposed by Lott et al. (1980) using borehole evidence from offshore South-West England.

\section{ACKNOWLEDGEMENTS}

We are indebted to Professor Malcolm Hart (Polytechnic Southwest) for his assistance during the course of this study. We wish to thank the technical staff of Polytechnic Southwest and Richard Hodgkinson (Natural History Museum) for their assistance in preparing specimens. For their advice and help in providing specimens for study we thank Pete Manley (Polytechnic Southwest), Kelvin Boot (Exeter Museum), Dr Graham Elliott, Dr Geoff Adams and Dr John Whittaker (all Natural History Museum), and also Dr Nigel Ainsworth (Paleo Services) and Professor John Murray (Southampton University. Dr Paul Taylor (Natural History Museum) resolved the identity of the Wilmington Sands specimens. This paper is published with permission kindly granted by BP Research.

\section{Manuscript Received February 1991 \\ Manuscript Accepted November 1991}

\section{REFERENCES}

Ainsworth, N.R. \& Horton, N.F. 1986. Mesozoic micropalaeontology of exploration well Elf 55/30-1 from the Fastnet Basin, offshore southwest Ireland. J. micropalaeontol., 5, 19-29.

Ainsworth, N.R., Horton, N.F. \& Penny, R.A. 1985. Lower Cretaceous micropalaeontology of the Fastnet Basin, offshore southwest Ireland. Marine Petrol. Geol, 2, 341-349.

Ainsworth, N.R., O'Neill, M., Rutherford, M.M., Clayton, G., Horton, N.F. \& Penny, R.A. 1987. Biostratigraphy of the Lower Cretaceous, Jurassic and uppermost Triassic of the North Celtic Sea and Fastnet Basins. In: Brooks, J. \& Glennie, K. (eds): Petrolcum Geology of North West Europe, 611-622. Graham \& Trotman, London.

Andreieff, P., Bouysse, P., Curry, D., Fletcher, B.N., Hamilton, D., 
Monciardini, C. \& Smith, A.J. 1975. The stratigraphy of post-Palaeozoic sequences in part of the Western Channel. Phil. Trans. R. Soc., A279, 79/97.

Arnaud-Vanneau, A. 1980. Micropaléontologie, palaéoécologie et sédimentologie d'une plate-forme carbonaté de la marge passive dela Téthys; L'Urgonien du Vercors septentrional et dela Chartreuse. "Geologie Alpine" Memoir11, 1-3. Publie avec le concours de la societé National Elf-Aquitaine.

Carter, D.J. \& Hart, M.B. 1977. Aspects of mid-Cretaceous stratigraphic micropalaeontology. Bull. Br. Mus. nat. Hist. (geol), 29, 1-135.

Curry, D., Hamilton, D. \& Smith, A.J. 1970. Geological and shallow subsurface geophysical investigations in the Western Approaches to the English Channel. Rep. Inst. geol. Sci. 70/3, 1-12.

Edwards, R.A. 1979. Diagenesis of Limestones from the Upper Greensand at Wolborough, South Devon. Proc. Ussher Soc., 4, 326-340.

Godwin-Austen, R.A.C. 1842. On the geology of the south-east of Devonshire. Trans. geol. Soc. Lond., 6 (2), 433-439.

Gusic, I. 1981. Variation, range, evolution and biostratigraphy of Palorbitolina lenticularis in the Lower Cretaceous of the Dinaric Mountains in Yugoslavia. Palaont. Z., 55, 191-208.

Hamblin, R.J.O. \& Wood, C.J., 1976. The Cretaceous (Albian-Cenomanian) stratigraphy of theHaldon Hills, south Devon, England. Newsl. Stratigr., 4, 135-149.

Hancock, J.M. 1961. The Cretaceous system in Northern Ireland. Q. Il. geol. Soc. Lond., 117, 11-36.

Hancock, J.M. 1989. Sea-level changes in the British region during the Late Cretaceous. Proc. Geol. Ass., 100, 565-94.

Hart, M.B. 1971. Micropalaeontological evidence of mid-Cenomanian flexturing in south west England. Proc. Ussher Soc., 2, 315-25.

Hart, M.B. 1973. Some observations on the Chert Beds (Upper Greensand) of south west England. Proc. Ussher Soc., 2, 599-608.

Hart, M.B. 1982. The Marine Rocks of the Mesozoic. I $n$ : Durrance, E.M. \& Lamming, D.J.C. (eds): The Geology of Devon, 179-203, Exeter University Press.

Hart, M.B. 1983. Planktonic foraminifera from the Cenomanian of the Wilmington quarries (SE Devon) Proc. Ussher Soc., 5, 405-410.

Hart, M.B.\& Tarling, D.H. 1974. Cenomanian palaeogeography of the North Atlantic and possible mid-Cenomanian eustatic movements and their implications. Palaeogeogr., Palaeoclimatol., Palaeoecol., 15, 95-108.

Hart, M.B. \& Williams, C.L. 1990. The Upper Greensand in East Devon: new data but old problems. Proc. Ussher Soc, 7, 273-278.

Hart, M.B. Manley, E.C. \& Weaver, P.P.E. 1979a. A biometric analysis of an Orbitolina fauna from theCretaceous succession at Wolborough, S. Devon. Proc. Ussher Soc., 4, 317-326.

Hart, M.B., Weaver, P.P.E. \& Harris, C.S. 1979b. Microfaunal investigation of Shapwick Grange Quarry, East Devon. Proc. Ussher Soc., 4, 312-316.

Hinde, G.J. 1904. On the Structure and Affinities of the Genus Porosphaera Steinmann. J.R. Micr. Soc. 1-25.

Hofker, J. Jr. 1963. Studies on the genus Orbitolina (Foraminiferida). Leidse geol. Meded., 29, 181-254.

Hofker,J.Jr. 1966. Studies on the family Orbitolinidae. Palaeontographica (A), 126, 1-34.

Hume, W.F. 1897. The Cretaceous strata of County Antrim. Q. Il. geol. Soc. Lond., 53, 540-606.

ICZN. 1990. Opinion 1587. Orbitolina d'Orbigny, 1850(Foraminiferida): Orbulites concava Lamarck, 1816 confirmed as the type species. Bull. Zool. Nomenclat., 47, 141-142.

Jarvis, I. \& Woodroof, P.B. 1984. Stratigraphy of the Cenomanian and Basal Turonian (Upper Cretaceous) between Branscombe and Seaton, SE Devon, England. Proc. Geol. Ass., 95, 193-215.

Jarvis, I., Leary, P.N. \& Tocher, B.A. 1987. Mid Cretaceous (Albian Turonian) stratigraphy of Shapwick Grange Quarry, SE Devon, England. Mesozoic Research, 1, 119-134.
Jukes-Browne, A.J. \& Hill, W. 1900. The Cretaceous rocks of Britain. 1, Gault and Upper Greensand. Mem. geol. Surv. U.K., London, 499pp.

Kennedy, W.J. 1970. A correlation of the Uppermost Albian and the Cenomanian of south-west England. Proc. Geol. Ass., 81, 613-677.

Lott, G.K., Knox, R.W.O'B., Bigg, P.J., Davey, R.J. \& Morton, A.C. 1980. Aptian - Cenomanian stratigraphy in boreholes from offshore south-west England. Rep. Inst. Geol. Sci., 80/8, 1-12.

McGugan, A. 1953. Upper Cretaceous Foraminifera from Northern Ireland. J. Paleont., 31, 329-348.

Meyer, C.J.A. 1874. On the Cretaceous rocks of Beer Head, and the adjacent cliff sections, and on the relative horizons therein of the Warminster and Blackdown fossiliferous deposits. Q. Jl. geol. Soc. Lond., 30, 369-393.

Owen, H.G. 1984. The Albian Stage: European province chronology and ammonite zonation. Cretaceous Research, 5, 329-344.

Parker, W.K. \& Jones, T.R. 1860. On the Nomenclature of the Foraminifera. Ann. Mag. Nat. Hist., 6, 29-40.

Reid, R.E.H. 1971. The Cretaceous rocks of north-eastern Ireland. Irish Nat. J., 7, 105-129

Rey, J., Bilotte, M. \& Peybernes, B. 1977. Analyse biostratigraphique et paleontologique de l'Albien marin d'Estramadura (Portugal). Geobios, 10, 369-393.

Schroeder, R. 1962. Orbitolinen des Cenomas Sudwesteuropas. Paläont. Z., 36, 171-202.

Schroeder, R. 1963. Palorbitolina, ein neues Subgenus der Gattung Orbitolina (Foram.). N. Jb. Geol. Paläont., Abh., 117, 346-359.

Schroeder, R. 1975. General evolutionary trends in Orbitolinas. Rev. esp. Micropaleont., Numero especial, 117-128.

Schroeder, R. 1985a. Orbitolina (Orbitolina) sefini Henson, 1948. In: Schroeder, R. \& Neumann, N. (eds): Les grands Foraminifères du Crétacé moyen de la région méditerranéene. Geobios Mémoire Spécial, 7, 66-68.

Schroeder, R. 1985a. Orbitolina (Orbitolina) concava (Lamarck, 1816). In: Schroeder, R. \& Neumann, N. (eds): Les grands Foraminifères du Crétacé moyen de la région Méditeranéene. Geobios Mémoire Spécial, 7, 62-66.

Schroeder, R. \& Simmons, M.D. 1988. Case 2663. Orbitolina d'Orbigny, 1850 (Foraminiferida): proposed confirmation of Orbulites concava Lamarck, 1816 as the type species. Bull. Zool. Nomenclat., 45, 254-261.

Schroeder, R. \& Simmons, M.D. 1989. The type species of the genus Orbitolina d'Orbigny, 1850 (Foraminifera). J micropalaeontol, 8, 87-90.

Schroeder, R., Simmons, M.D., Hart, M.B. \& Williams, C.L. 1986. A note on the occurrence of Orbitolina (Orbitolina) sefini Henson, 1948 (Foraminiferida) in the UpperGreensand of S.W. England.Cretaceous Research, 7, 381-387.

Selwood, E.B., Edwards, R.A., Simpson, S., Chester, J.A., Hamblin, R.J.O., Henson, M.R., Riddols, B.W. \& Waters, R.A. 1984. Geology of the Country around Newton Abbot. Memoir of the British Geological Survey.

Simmons, M.D. 1990. Aspects of the micropalaeontology and stratigraphy of Cretaceous shelf carbonates from the Oman Mountains. Unpublished Ph.D. thesis, Polytechnic South West, Plymouth, United Kingdom, pp.

Simmons, M.D. \& Hart,M.B. 1987. The biostratigraphy and microfacies of the early to mid-Cretaceous carbonates of Wadi Mi'aidin, Central Oman Mountains. In: Hart, M.B. (ed.). Micropalaeontology of carbenate environments, 176-207. Ellis Horwood, Chichester.

Simmons, M.D., Williams, C.L. \& Hart, M.B. 1992. Sea-level changes across the Albian-Cenomanian boundary in South-West England. Proceedings of the Ussher Society, 7, 408-412.

Williams, C.L., Hart, M.B. \& Leary, P.N. 1988. Foraminifera and correlation of the UpperGreensand, Branscombe, south-east Devon. Proc. Ussher Soc., 7, 97-99.

Wright, C.W., Kennedy, W.J. \& Hancock, J.M. 1984. Stratigraphic introduction. In:Wright, C.W. \& Kennedy, W.J.: The Ammonoidea of the Lower Chalk, part 1 Monogr. Palaeontogr. Soc., 567, 1-37. 